stem; in the second we have leaves and their modifications; in the third, inflorescence and the whorls of the flower, while the fourth presents us with the pistil, ovule, and seed, and the organs of flowerless plants. Many of the drawings are, strictly speaking, diagrams, that is, artificial representations of typical structure. They are well and clearly drawn, and sufficientiy coloured to add to their lifelikeness. With these sheets, and either Henslow's series, or better still, a few hand-made ones on a Jarger scale, and actually taken from life, the botanical lecturer would be well provided; and the comparatively low price at which they are published ought to insure for them a very large sale. The handbooks which accompany them are admirably drawn up.

From China samples of Poyang Lake coal have been forwarded to the Admiralty authorities in the hope that they may be found useful for the navy in that station.

THE Government of India has taken further measures for carrying on coal borings in Central India, but only in Berar, and not in the Nizam's dominions.

THE Indian Government have again deputed Mr. T. W. H. Hughes, of the Geological Survey Department, to prosecute the investigation of the Wurda River coal-beds in the Central Provinces, and to report on the line of railway best calculated to develop the collieries.

OUR Darjeeling hill district of India is likely at length to experience a development of its mineral produce, instead of being left to depend on tea culture. Limestone, copper, and iron have been discovered not only in the Darjeeling territory, but also in the lately annexed Dooars of Bhootan. The Nepaulese have applied to work the iron ore, and the Commissioner of Kooch Behar has been authorised to divide the tract into sections, and to let out the mineral privileges by the year to the highest bidder.

A VERY important discovery of silver is reported from Copiapo, in Chile, which has a large silver district. EI Carmen Mine is now producing 16,000 marcs of silver per month; that is 128,000 ounces, worth about 32,000 .

Mr. James Galbraitri sends to the Ararat and Pleasan Creek Advertiser (Victoria), of Sept. i6th, an account of some huge boulders found near the townships of Hamilton and Coleraine, which he believes to have been deposited there by the agency of ice. He states that the whole of the western district of Victoria is covered with boulder clay. The ironstone gravel called buck-shot, which is found in patches on the surface and at a short distance below the surface, all over the plains to the south of Ararat and Beaufort, is, no doubt, a deposit from floating ice. The "grey stone" on the Ararat and Port Fairy "road has been floated to its present position by ice; and a number of granite boulders on the road between Moyston and Ararat, some of them a great deal larger than the "grey stone," must have been brought to their present position by the same agency. No polished or striated rocks have, however, as yet been detected in the colony.

WE learn from the New York Times that an ice machine, constructed on Tellier's principle, is now being exhibited in the United States. The material used is gaseous ammonia, which is liquefied by pressure. It is said that the machine will make 1oo tons a day, at a cost of four or five shillings per ton; and that the ice made by it is transparent and durable. The cooling effect of the vaporisation of liquefied ammonia may be applied to chambers containing articles of food to be preserved, or refrigerators might be constructed on any scale. The holds of ships could thus be converted into refrigerating chambers with the greatest ease, offering a ready means for the conveyance of meat from one port to another in a wholesome state.

\section{BALLOON ASCENTS FOR MILITARY PURPOSES}

II.

BEING detained in England by unavoidable circumstances for some time longer than I expected, I will try to give the British public an adequate view of the action of our French Institute in the matter of balloon navigation; and will confine my criticism to an exposition of M. Dupuy de Lome's own views, which were supported by the Government, so far as to give to this learned man a credit of nearly 2,000 . for the construction of his balloon. Perhaps the observations I bave published in the Liberté and offered to some of his assistants in private conferences, have produced some alteration in the original scheme. It is a matter of which 'I cannot be made aware by any means, and I must suppose things to be as they were when I left Paris in my own balloon.

M. Dupuy de Lome's balloon was to be constructed out of silk, and I understood that people were engaged in looking after the stuff in different Parisian fancy shops. But it requires a great deal of search to find silk enough to construct a large balloon somewhat larger than Mr. "Coxwell's "Research" and having a larger surface besides in consequence of its intended elongated form, the spherical form being, as is known, the one which offers the largest capacity for the smallest surface.

It may be well to remark that balloons are somewhat elongated in "the present fashion of building them, the elongation being vertical instead of horizontal as required by $M$. Dupuy de ' Lome's scheme. But the élongation of the balloon is a thing of which we will speak more fully in another place.

M. Dupuy de Lome was not afraid to have his balloon shaped like an egg, or, rather, like a fish with two tails and no head, but he did not wish to try it with pure hydrogen gas. It is not because he thinks that hydrogen gas is too expensive or too difficult to prepare, it is only because he supposes that hydrogen gas would escape in spite of varnishing. I cannot agree with him in this respect, not only because my friend Giffard's balloons have proved perfectly hydrogen-tight, but principally because ordinary balloons filled with hydrogen have done good service. Amongst these balloons I may mention the one which conducted the unfortunate Worth to be lodged in a Cologne cell, not by any fault of its gas-holding pöwer, but mërely because aëronauts were foolish enough to open their valve when Prussians were firing at them, and preferred trusting to Prussian humanity to relying upon the dark mantle of the night.

Official people engaged in ballooning seem to have strong prejudices against hydrogen gas, as may be noticed from their acts; the battery I had caused to be constructed for filling poor "Liberté," having been wholly dișregarded by them as unfit for use.

Many inventors have published descriptions of working aërostats, but very few of them were really professional aëronauts. I shall be justified by facts in stating that scarcely any of them was in a position to form an adequate idea of the most essential features of any really scientific scheme. Almost everyone of them has forgotten that the principal condition of success is an easy working: $M$. Dupuy de Lome has not avoided that fault, and his balloon is to be shaped, as we have remarked, like a fish, which is to be kept in an horizontal position. That condition is very difficult to accomplish when you have to look to so many other things at the same time. M. Dupuy de Lome is so well aware of the difficulty of having his balloon always progressing horizontally, that he proposes to get rid of it by keeping the balloon always filled either with gas, or with ordinary air by means of a pump. It is an instance of avoiding our old French saying, Le remède est pire que le mal. This saying is so much the more justified, that $M$. Dupuy de Lome is not contented with sending air into his bal. loon when it is required to fill it. He has constructed ready for the purpose a special balloon, which is to be enclosed within the large one, and which being alternately filled and unfilled according to the requirements of the external pressure, keeps the balloon always in a stäte of full expansion. The pressure inwards is always a little greater than the pressure outwards, which is in itself a new objection, as this artificial pressure increases the rate of escape for the gas by the small holes which are unavoidably so numerous in the' whole surface. Besides, if there are some defective places, they may probably be opened by that pressure.

As you may understand from this explanation, M. Dupuy de Lome was very careful, and his scheme is worked out with de required detail, to show the corollaries which follow from the first assumptions. M. Dupuy de Lome being a very clever ship con- 
structor, is readly to meet the diffeulties, but he was not wiliting to avoid them at once by having a more simple scheme to work out. It is so much the more to be wondered at, if this clever aëronaut has not adopted this policy, inasmuch as he does not profess to go against the wind, but to design a contrivance which may help aëronauts in using the wind for a certain purpose, as returning to Paris from a town located at some distance, as Lille, Le Mans, \&c. M. Dupuy de Lome intends to attain the desired result by making a definite angle with the direction of the reigning wind, which supposes on the part of the aerronant some previous knowledge of the state of atmospheric currents, their change of duration, and different directions at different elevations; the principal feature of his intended directing balloon being the grand idea of having the motive power like an auxiliary implement for giving to the balloon differential motions. It does not, of course, prevent the aeronaut from using the deflections and variations of the wind according to the elevation of his balloon at any moment. The working out of these aèrial manouvies supposes necessarily that aërial navigators can know at any moment the place where they are. It requires constant attention from the aerrial travellers, who are supposed to be supplied with every possible instrument for looking over the land and finding the places on the map prepared for that very purpose. It would be of itself a most interesting chapter, the better construction of such maps, as well as the determination of the means by which public anthoritics could give warnings to the aërial travellers. But in the present state of things, I should not be justified if I dicl not abstain from giving details which may prove useful to the invaders of my native land. I will be satisfied with saying, moreover, that the taking of the point in sailors' fashion is quite out of the question. The only condition is the view of the land remaining always at the command of the observer, or only being lost for short intervals, during which more than the usual attention is required. I have invented an apparatus called an aërial planchette, for helping aerronauts in the determination of their way, but from the experience of my last excursion I have lost every confidence in niy instrument. I think that it is quite useless; the only thing required being good maps and better eyes, helped by powerful opera-glasses. The power of these can be enlarged by a very simple contrivance, which I mention merely to show that I know what is still to be done in this respect.

The question of the motive power to be employed is not of so much importance as was supposed at the frist instance; and it is very easy to understand why, admitting that we want only a slow motion. I should not object, of course, to a quick displacenent; but $I$ am satisfied it cannot be obtained except by contrivances very difficult to imagine, and even more to realise, and besides it is not required for the special purpose in view, the returning to Paris from a French city which German armies have not occupied. The rate of motion will be improved by degrees, and will not amount to a large increase, except by the use of steam engines, whicli requires a great many preliminary steps to prevent the gas of the balloon from being lighted by the fire from the furnace, which would lead to the destruction of the balloon and of the aëronauts. The simplest contrivance will be the best if it proves useful. I should advise to arrange the notor apparatus so that it could be used by hand, and, besides, that it could be very easily thrown overboard like ballast in case of need. These two conditions being of much importance for our purpose, if I start for Paris, which I hope will be the case, I shall adhere strictly to them.

I have no objection to use a rudder, which may be constructed in a mamner very easy to understand, but I should feel very much disposed to dispense with it. I think that a propelling machine may be arrangerl so that no rudder at all will be put into operation. I am afraid to give more substantial explanations, which could hardly be offered without giving a full knowledge of my intended construction, which is not my purpose.

T'he contributions of M. Dupuy de Lome to the Comptes rendius, have been sharply commented upon by the Aeronaut, a special paper devoted to the aërial navigation worked out by the plus lowr't que l'air system, as inaugurated by Lalandelle and Nadas, and many other gentlemen of very little or no scientific qualifications. But every scientific man must confess that these interesting papers constitute by themselves a very valuable acquisition to reireral knowledge, independently of their special ain. M. Dupuy de Lome has given at the same time many calculations to show to what elevation a given balloon can attain under the conditions he has adopted, viz., constant fulness, and a certain excess of internal pressure for giving it a stability of form and of equilibrium.

Without quoting M. Dupuy de Lome's paper, and even cor. recting some parts of it, 1 will give a rough iden of the analytical questions involved in the calculation of the circumstances of an aerrostatical ascent. I suppose, firstly, that the air has no horizontal movement at all, and that the only questions are to ascertain the elevation which the balloon may reach, the time that may be required, and the velocity with which the balloon ascends at the various points of its vertical course, as well upwards as downwards. There are hesides two accessory suppositions which are required. The first is, that the balloon does not lose its gas by any exosmose during the experiment; and the second is that the temperature of the air, as well as the degree of moisture, is not altered in any degree. These conditions are hardly to be expected, but they are required for mathematically working out the analytical equations.

M. Dupuy de Lome, however, would not have been placed in a position to proceed with his calculations, if he had not very cleverly evaded the consideration of the other conditions, which are insuperable, owing to nur imperfect knowledge of the atmosphere, as we shall see hereafter.

W. DE FONVIELIE

\section{PROF. WILLIAMSON'S INAUGURAL LECTURE TO THE FACULTY OF SCIENCE AT UNIVERSITY COLLEGE, LONDON}

THE great value of scientific knowledge as a means of culture, a promoter of civilisation, and one of the most powerful levers of national prosperity, seems at least to receive its due acknowledgment in the land of Bacon and New'ton, Sir Humphry Davy and Faraday. The recent efforts to introduce science into the public schools of England appear as a consequence of this recognition. A great variety of opinion, however, exists as regards the mode by which scientific knowledge ought to be imparted to the people. Some believe that a young farmer ought to be taught agricultural chemistry, the man at the furnace the chemistry of iron melting, and the maker of colours the chemistry of colours. "This is what is called by many "technical education," for the promotion of which great efforts have been made of late. Technical education in this sense would be a mistake. It would not be difficult to show that it is impossible to teach, with any considerable effect, agricultural chemistry, which is the application of certain chemical principles to Agriculture, without a knowledge of these principles. These, with others, form part of the science of Chemistry, and it is clearly absurd to isolate them and teach their application in some par. ticular case. The working classes of England want a knowledge of the elements of pure science; and they are sure to make useful application of this knowledge as soon as an opportunity offers itself. In this sense Professor Williamson expresses himself in his admirable lecture, "A Plea for Pure Science," * which on account of its sound views on some of the most important questions of the day, we recommend to the attention of our readers. On p. 3 Prof. Williamson says, "Now there are in edx: cation two great national parties, corresponding to the two most different points of view from which the preparation of any young person for his career in life can be considered. I submit that the progress of education will be proportional to the consistency and completeness with which the functions of these two parties are systematised and developed.

"The first step towards that object is to know and acknowledise their respective characteristics.

"One party looks to the special duties for which a young person has to be prepared and the material difficulties which he is ex. pected to encounter. They see that the success and happiness of each individual are propertional to the efficiency with which he discharges the aggregate of the special duties of his station in life; and they accoidingly recommend that each youth be placed in circumstances which may induce him to imitate accurately the doings of some one who is known to be successful in a station. such as he is intended to occupy. The other party looks to the general qualifications which experience has shown to be most important for any success in life; and to the means by which they are most effectually acquired. They see that men who have been taught to understand and apply the best-known general principles are able to master a given set of practical details with a facility and completeness which other men do not attain. They know that a general principle of nature is an instrument of " "A Plca for Pure Science." By A. W. Williamson, Ph.D., F.R.S. 